\title{
Morphometric evaluation of multirooted artificial teeth used for endodontic training
}

\author{
Avaliação morfométrica de dentes artificiais polirradiculares utilizados para \\ treinamento endodôntico

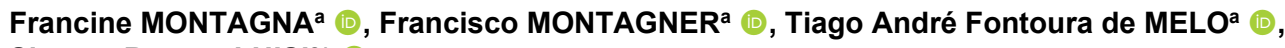 \\ Simone Bonato LUISI ${ }^{\mathrm{a} *}$ (D) \\ aUFRGS - Universidade Federal do Rio Grande do Sul, Faculdade de Odontologia, Departamento de Odontologia \\ Conservadora, Porto Alegre, RS, Brasil
}

How to cite: Montagna F, Montagner F, Melo TAF, Luisi SB. Morphometric evaluation of multirooted artificial teeth used for endodontic training. Rev Odontol UNESP. 2021;50:e20210031. https://doi.org/10.1590/1807-2577.03121

\begin{abstract}
Resumo
Introdução: Dentro da prática odontológica, os profissionais podem receber diversos casos de urgência, principalmente relacionados a problemas endodônticos e, para atendê-los, há a necessidade de um extenso treinamento pré-clínico prévio, sendo uma das principais dificuldades a busca por modelos que simulem a morfologia dentária. Objetivo: Comparar a morfometria de dentes artificiais polirradiculares à literatura. Material e método: Os dentes artificiais (Primeiro Pré-molar Superior, Primeiro Molar Superior e Primeiro Molar Inferior) foram doados pelos fabricantes: Fábrica de Sorrisos (FS) e IM do Brasil Ltda. (IM), totalizando 30 dentes. Foi realizada mensuração do comprimento total do dente e o da raiz, da altura e das dimensões vestíbulo-palatina e mésio-distal da coroa, com paquímetro digital. Os dados foram dispostos em uma planilha de cálculo e realizou-se a análise estatística [ANOVA ou Kruskal-Wallis e, após, teste de Dunnett $(\alpha=5 \%)]$. Resultado: A amostra de molares superiores da empresa FS apresentou todas as variáveis dentro dos padrões morfométricos descritos na literatura. Os demais grupos dentários apresentaram diferenças estatisticamente significantes, mantendo ou não certa proporcionalidade. Conclusão: De todos os grupos dentários pesquisados o molar superior da empresa FS foi o único que apresentou todos os aspectos morfométricos externos de acordo com os dados da literatura.
\end{abstract}

Descritores: Dente artificial; educação; endodontia

\begin{abstract}
Introduction: Dental practice professionals encounter several urgency cases, mainly related to endodontic problems. To attend to these, professionals need extensive prior preclinical training, being one of the main difficulties the search for models that simulate dental morphology. Aim: To compare the external morphometry of multirooted artificial teeth to literature. Material and method: The artificial teeth (Upper First Premolar, Upper First Molar and Lower First Molar) were donated by the manufacturers: Fábrica de Sorrisos (FS) and IM do Brasil LTDA (IM), totaling 30 teeth. The total length of the tooth and root, height and buccal-palatal and mesial-distal dimensions of the crown were measured with a digital pachymeter. The data were placed in a spreadsheet and the statistical analysis was performed [ANOVA or Kruskal-Wallis and then, Dunnett's test $(\alpha=5 \%)]$. Result: The Upper Molar samples of the company Fábrica de Sorrisos presented all variables within the morphometric patterns described in the literature. The other dental groups presented statistically significant differences, maintaining or not a certain proportionality. Conclusion: Of all the dental groups analyzed, the upper molar from the company Fábrica de Sorrisos was the only one that presented all the external morphometric aspects according to literature.
\end{abstract}

Descriptors: Artificial teeth; education; endodontics. 


\section{INTRODUCTION}

Within the dental practice, professionals can encounter several urgent cases, mainly related to endodontic problems and it is important to know about coronary openings, for example, aiming at pain resolution in a Primary Care context. Considering the complexity of endodontic treatment, it is necessary to educate and train dentistry students in this specialty through extensive pre-clinical training, ensuring that they are prepared for emergency care as general practitioners. Also, it is necessary to carry out an adequate treatment, anticipating the possible complications and outcomes of this treatment ${ }^{* * 1-4}$.

Since pre-clinical training is extremely important both for the development and acceptable performance of dentistry students in endodontic practice and for dentists in continuing education courses, it is necessary to overcome one of the biggest challenges found in this form of teaching, the search for models that accurately simulate tooth morphology and the root canal system ${ }^{3,5}$.

Traditionally, this pre-clinical education, both in undergraduate and in courses for continuing professional development, was carried out almost exclusively through the use of extracted natural teeth ${ }^{* *} 6-11$. However, this model has several disadvantages, including the difficulty of obtaining them, mainly due to ethical requirements established from Law 9,434 of 199712, which provides for the removal of organs and tissues for transplants, treatments, and other measures. The law makes a crime to transport, store or distribute human tissues unless there is the patient's consent. There is a paradigm shift from the emergence of the National Oral Health Policy, which provides for the emergence of health prevention policies, expansion, and qualification in the three levels of care - primary, secondary, and tertiary - directly affecting the longer maintenance of teeth ${ }^{13}$. Other disadvantages are the possibility of cross-infection, requiring the adequacy of these teeth, through the removal of amalgam fillings and subsequent sterilization, based on infection

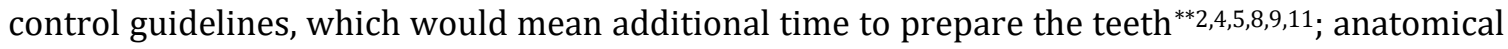
variation, exemplified by incomplete root formation, extensive loss of tooth structure, canals atresia, root canal curvature, which hinders the standardization of teaching and the individual preparation and assessment of students' performance ${ }^{* * 2,4,8}$. Therefore, there was a stimulus for the development of alternative resources for preclinical endodontic education ${ }^{5,10}$.

Thus, artificial teeth - produced with opaque resin - which reproduce the anatomical characteristics of natural teeth, have been developed and used for pre-clinical teaching1,4,7-9,11. These teeth bring some advantages, such as standardization, radiopacity, availability, ease of obtaining and replacement, as well as the absence of risk of cross-infection, being also cheaper ${ }^{* 2,4,7,8,11,14}$. Thus, students could train in different scenarios as many times as necessary for their learning, acquiring the manual skills and radiographic interpretation necessary for their training, and being evaluated in a standardized and validated way due to the uniformity of artificial teeth, which guarantees very similar conditions during the teaching of the technique ${ }^{* * 1,4,7,10}$. The disadvantages of these teeth include a discrepancy in the dimensions of the available models and, several times, an unreliable morphology ${ }^{15}$. This difficulty raises questions about the efficiency of preclinical learning exclusively in artificial models ${ }^{3,9}$.

Knowing that one of the main difficulties of this training is the search for models that simulate the dental morphology, this study aims to compare the external morphometry of polyarticular

\footnotetext{
** Fochuk L. Evaluation and comparison of several tooth replicas used for endodontic treatment in pre-clinical [dissertation]. [Almada]: Higher Institute of Health Sciences Egas Moniz; 2017.
} 
artificial teeth with the literature. The null hypothesis is that there are no differences between commercially found artificial teeth and literature data.

\section{MATERIAL AND METHOD}

This observational, descriptive, in vitro study was approved by the Research Committee (COMPESQ) of the Faculty of Dentistry of the Federal University of Rio Grande do Sul (FO-UFRGS) and carried out at the Dental Materials Laboratory of FO-UFRGS.

Thirty artificial endodontic teeth were obtained through donations from two commercial companies: Fábrica de Sorrisos (Arujá, São Paulo, Brazil), FS group, and IM do Brasil Ltda. (São Paulo, São Paulo, Brazil), IM group. Each company donated five teeth from each dental group maxillary first premolar, maxillary first molar, and mandibular first lower molar - totaling fifteen teeth per company.

\section{Sample Calculation}

According to a previous study in the literature ${ }^{16}$ and to detect a standard deviation of at least 1.5 units between the means of the measurements observed in the groups, reaching a statistical power of $90 \%$ with a significance level of $5 \%$, we calculated the need for five teeth per group.

\section{Acquisition of data regarding the external morphometry of the test groups}

We used a digital caliper to record the total length (TL) of the tooth and the buccopalatal (BP) and mesiodistal (MD) dimensions of the crown (Mitutoyo, Suzano, São Paulo, Brazil). The caliper was calibrated at $0 \mathrm{~mm}$ and dimension measurements were taken at the most prominent point of these faces. The tooth neck was identified and, from this point, we measured the root length (RL) and the crown length (CL) also using a digital caliper.

For maxillary premolars, the records of total tooth length and root length were performed both on the buccal surface (TL_1MPM_V and RL_1MPM_B) and on the palatal surface of the tooth (TL_1MPM_P and RL_1MPM_P). For maxillary first molars, these same values were obtained by measuring individually the roots regions of the mesiobuccal (TL_1MM_MB and RL_1MM_MB), distobuccal (TL_1MM_DB and RL_1MM_DB) and palatal (TL_1MM_P and RK_1MM_P) roots. Likewise, in mandibular lower molars, the variables were measured both at the mesial root (TL_1MMO_M and RL_1MMO_M) and the distal root (TL_1MMO_D and RL_1MMO_D).

Each variable was measured three times and at different times to obtain an average. The same previously trained evaluator performed the three measurements.

\section{Acquisition of data regarding the external morphology of the control group}

Regarding the morphometric data of the control group, we included in these study findings from the literature of four authors ${ }^{17-20}$. The average of the data obtained for each of the variables was used: total tooth length, root length, crown height, and buccolingual and mesiodistal dimensions of the crown of natural human teeth. 


\section{Data analysis}

We entered data into a spreadsheet (Excel, Microsoft Windows, USA) and data analysis was performed using GraphPad Prism version 7.00 for Windows (GraphPad Software, La Jolla California USA, www.graphpad.com). The significance level adopted for all tests was 5\%. Data normality was tested using the Shapiro-Wilk test. We compared data between each group and the control group, as established from literature data. No comparison was made between the different test groups. In the case of parametric distribution of data, we applied the ANOVA test, followed by Dunnett's test of multiple comparisons. In the case of non-parametric data distribution, we adopted the Kruskal-Wallis test, followed by the Dunnett multiple comparisons test.

\section{RESULT}

Figure 1 shows the results obtained for the variables total tooth length, root length, crown height, crown width in the buccolingual direction, and crown width in the mesiodistal direction, referring to the maxillary first premolars when compared to the literature.

For premolars, we observed a statistically significant difference between samples from the FS and control groups for the variables total buccal length of the tooth $(\mathrm{P}=0.0001$; post hoc ANOVA test Dunnett's Multiple Comparisons Test), total palatal length of the tooth $(\mathrm{P}=0.0001$; ANOVA post hoc Test of Dunnett's Multiple Comparisons Test), vestibular root length ( $\mathrm{P}=0.0001$; ANOVA post hoc Test of Dunnett's Multiple Comparisons) and palatal root length ( $\mathrm{P}=0.0015$; ANOVA post hoc test (Dunnett's Multiple Comparisons Test). The IM group showed a statistically significant difference for the variables total buccal length of the tooth $(\mathrm{P}=0.001$; ANOVA post hoc test Dunnett's Multiple Comparisons Test), total palatal tooth length ( $\mathrm{P}=0.001$; ANOVA post-hoc test Dunnett's Multiple Comparisons Test), and crown height $(\mathrm{P}=0.0411$; Kruskal-Wallis test post hoc Dunnett's Multiple Comparisons Test).

Figure 2 shows the results for total tooth length, root length, crown height, and buccolingual and mesiodistal dimensions obtained by comparing the maxillary first molars with literature data.

Maxillary molars revealed a statistically significant difference between the IM and control group samples for the variables buccolingual width $(\mathrm{P}=0.0004$; post hoc ANOVA test Dunnett's Multiple Comparisons Test) and mesiodistal crown width ( $\mathrm{P}=0.001$; ANOVA post hoc Test of Dunnett's Multiple Comparisons).

Figure 3 shows the results obtained from the comparison between the first lower molars and the control group, for the variables total tooth length and root length, as well as the buccolingual and mesiodistal height and width data of the crown.

For mandibular molars, we observed a statistically significant difference between the samples from the FS group, regarding the variable mesial total length of the tooth ( $\mathrm{P}=0.0032$; ANOVA post hoc Test of Dunnett's Multiple Comparisons Test), when compared to the control. For the IM group, there was a statistically significant difference, when compared to the control group, for the mesiodistal width variable $(\mathrm{P}=0.0161$; ANOVA post hoc Test of Dunnett's Multiple Comparisons). 

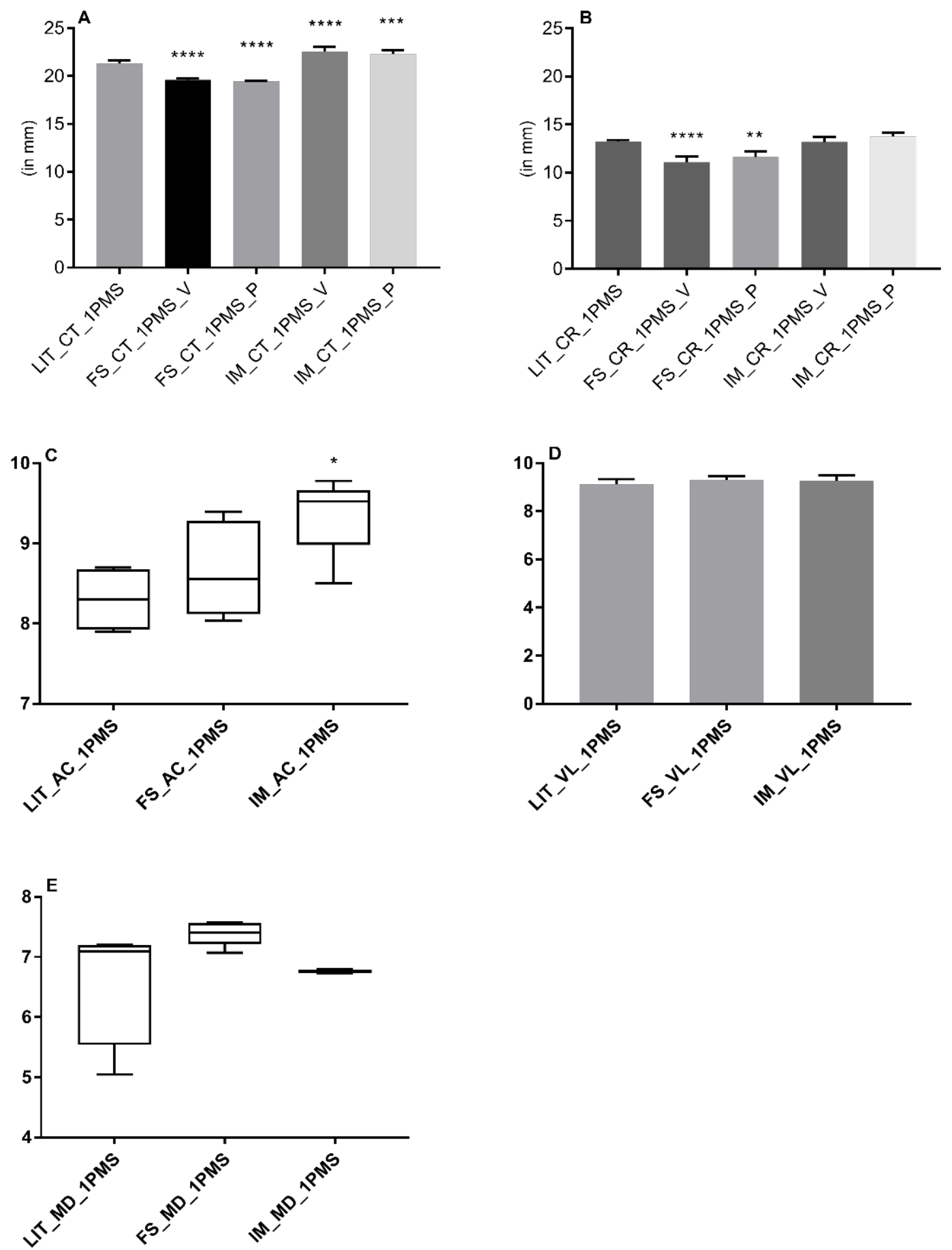

Figure 1. Graphs referring to data analyzed for Maxillary First Premolar (1PMS). Legend: A - graph of the mean total PMS length (CT) of the maxillary first premolar (1PMS) measured by the buccal surface $(\mathrm{V})$ and palate $(P)$; $B$ - graph of the mean root length $(C R)$ of the maxillary first premolar (1PMS) measured by the

buccal $(V)$ and palatal $(P)$ surfaces; $C$ - graph of the median crown height $(A C)$ of the maxillary first premolar (1PMS); $\mathrm{D}$ - graph of the mean of the buccolingual dimension (VL) of the maxillary first premolar (1PMS); $\mathrm{E}$ - graph of the median of the mesiodistal dimension (MD) of the maxillary first premolar (1PMS).

LIT is the control group, FS is the Fábrica de Sorrisos group and IM is the IM group from Brazil. Note: Asterisks represent a statistically significant difference, the greater the number of asterisks, the greater the difference. 

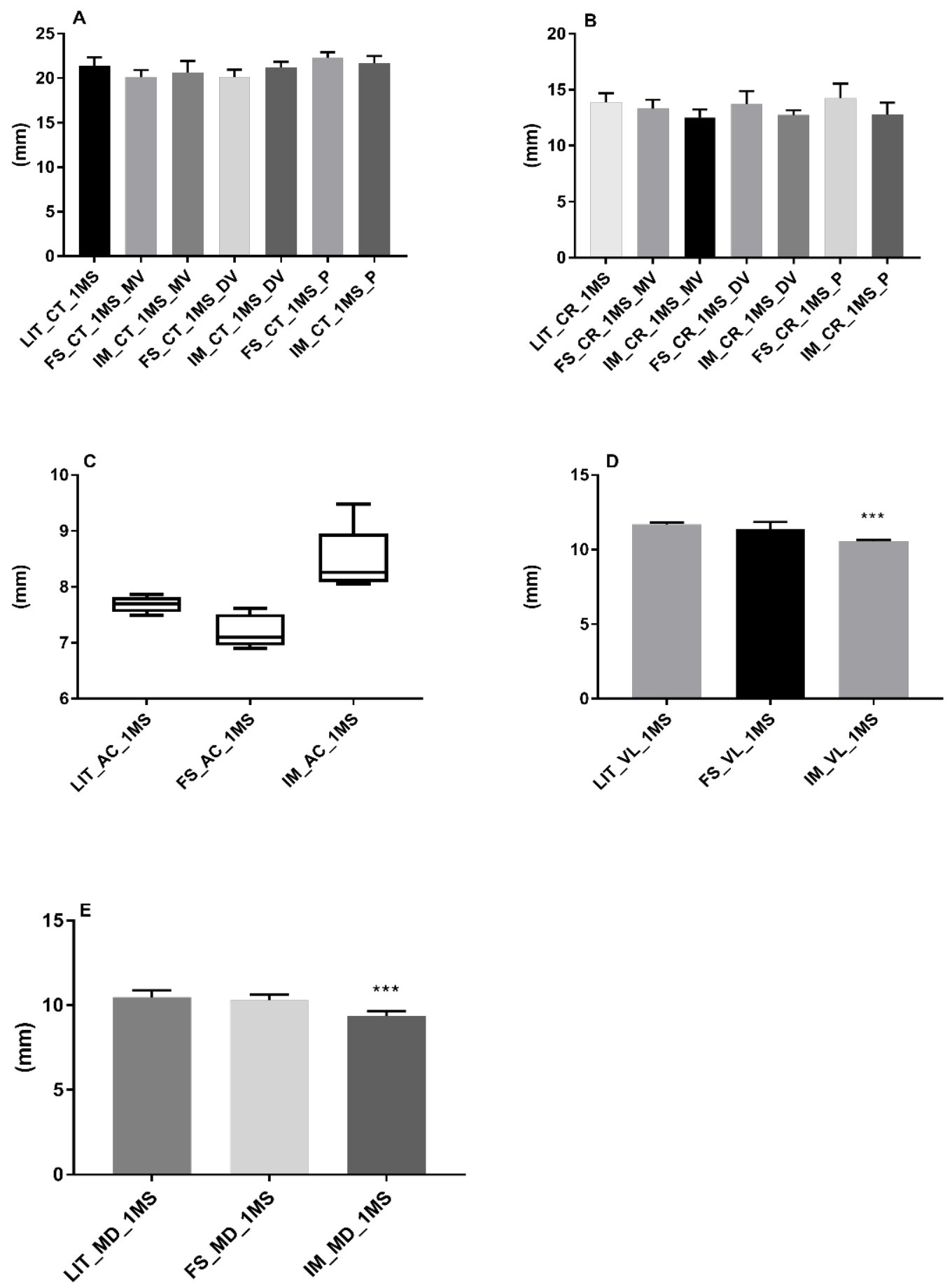

Figure 2. Graphs referring to the analyzed data for Maxillary First Molar. Legend: A - graph of the mean total length (CT) of the maxillary first molar (1MS) measured by the mesiobuccal (MV), distobuccal (DV), and palatal $(P)$ face; $B$ - graph of the mean root length $(C R)$ of the maxillary first molar (1MS) measured by the mesiobuccal (MV), distobuccal (DV) and palatal (P) surface; C - graph of the median crown height (AC)

of the maxillary first molar (1MS); D - graph of the mean of the buccolingual dimension $(\mathrm{VL})$ of the maxillary first molar (1MS); $\mathrm{E}$ - graph of the mean mesiodistal dimension (MD) of the maxillary first molar (1MS). LIT is the control group, FS is the Fábrica de Sorrisos group and IM is the IM group from Brazil. Note: Asterisks represent a statistically significant difference, the greater the number of asterisks, the greater the difference. 

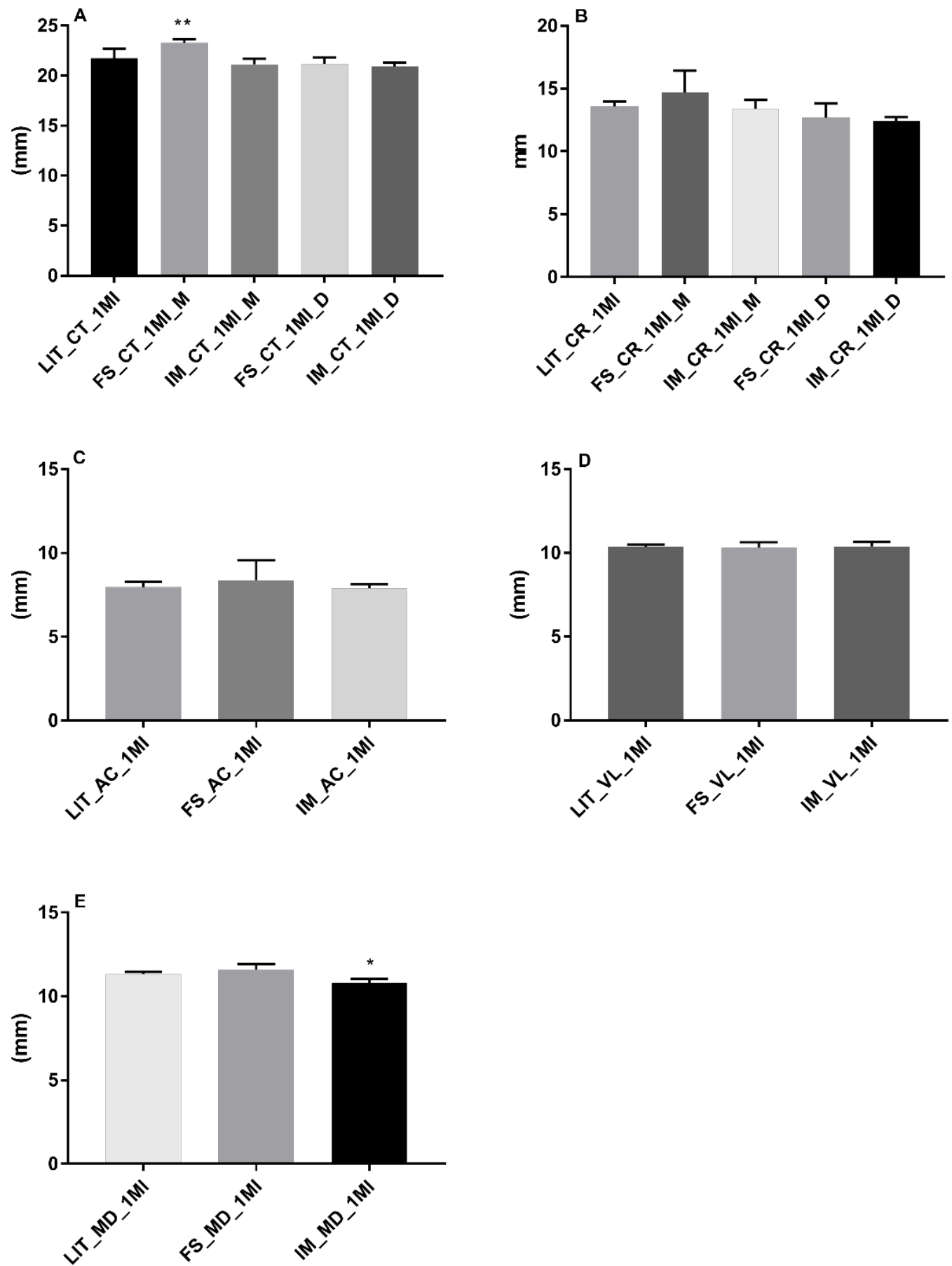

Figure 3. Graphs referring to data analyzed for Mandibular First Molar. Legend: A - graph of the mean total length (CT) of the mandibular first molar (1MI) measured by the mesial (M) and distal (D) face; $B$ - graph of the mean root length (CR) of the mandibular first molar (1MI) measured by the mesial $(M)$ and distal $(D)$ surfaces; $\mathrm{C}$ - graph of the mean crown height $(\mathrm{AC})$ of the mandibular first molar (1MI); D - graph of the mean of the buccolingual dimension ( $\mathrm{VL}$ ) of the mandibular first molar (1MI); $\mathrm{E}$ - mean the graph of the mesiodistal dimension (MD) of the mandibular first molar (1MI). LIT is the control group, FS is the Fábrica de Sorrisos group and IM is the IM group from Brazil. Note: Asterisks represent a statistically significant difference, the greater the number of asterisks, the greater the difference. 


\section{DISCUSSION}

The null hypothesis of this study of no morphometric differences between artificial teeth and data obtained from the literature on human maxillary first premolars and mandibular first molars was rejected. This corroborates the study by Reymus et al. ${ }^{21}$ that showed a difference between commercially available replicas and extracted natural teeth. On the other hand, in this study, the group of maxillary molars from the company FS presented all morphometric measures evaluated similarly to the data in the literature on human teeth.

The morphometric evaluation is one of the aspects to be considered when choosing artificial teeth such as morphological aspects ${ }^{15}$, Knoop microhardness ${ }^{22}$, and radiopacity ${ }^{23}$, which were not the object of this study, having been evaluated in other experiments $15,22,23$.

This paper did not aim at evaluating the internal anatomy. According to Vertucci et al. ${ }^{24}$ the internal anatomy of teeth is complex and can have up to eight different configurations of the root pulp space. Thus, knowledge of the morphology of the root canal and its frequent variations is essential for successful endodontic treatment. This expressive number of configurations makes most dentistry students consider the teaching of Endodontics stressful and complex ${ }^{25}$.

The study by Gancedo-Caravia et al. ${ }^{1}$ brings as an alternative the use of less complex anatomical models for the initial endodontic training of students. However, from the development of skills, more anatomically accurate models, with variations in the degree of difficulty would be indicated ${ }^{1,11}$.

According to Della Serra, Ferreira ${ }^{26}$, the pulp chamber follows the same format seen in the anatomy of the dental crown, but in proportionately smaller dimensions. Therefore, once the artificial model managed to be adequate in its size and external shape, the internal morphology would accompany it and would be a smaller anatomical equivalent when compared to the external shape. However, Mendes et al. ${ }^{15}$ did not observe the similarity between the internal and external anatomies of single-rooted artificial teeth, reporting the difficulty of reproducing the external anatomy in the internal one, since the shape of the crown is often not similar to that in the literature, except the maxillary lateral incisor of Fábrica dos Sorrisos company.

The natural teeth also present variations in their dimensions, influenced by numerous conditions such as gender, age, ethnicity, and head type of the individual ${ }^{26}$. The teeth of black male individuals are proportionally larger than teeth of individuals of the female sex and other ethnicities ${ }^{27}$, with small morphometric variations acceptable in artificial teeth, as long as a certain degree of proportionality is maintained ${ }^{15}$.

Therefore, we observed that all the variables that showed a statistically significant difference in the maxillary first premolars, when compared to the control group, respected a certain proportionality. The FS company presented lower values than those observed in the control group for total length - buccal and palatal - and root length - buccal and palatal. In turn, the IM company presented higher values for the variables total tooth length, when measured by buccal and palatal, and for crown height, when compared to the literature.

For the group of maxillary first molars from the IM company, the proportionality of the dimensions of the crown was respected, as even with a statistically significant difference for the variables buccolingual and mesiodistal crown width, both were smaller than those obtained in the literature.

On the other hand, the group of mandibular first molars from the IM company showed a statistically significant difference only for one of the crown variables, mesiodistal width, which was smaller than in the literature. The difference in only one of the crown dimensions suggests a change in the proportionality of the external morphometry and, consequently, a change in the shape of the crown. 
In the group of mandibular first molars from the FS company, there was a statistically significant difference in the mesial total length of the tooth, which was greater than in the control group. Although crown height and mesial root length did not present statistically significant values when compared to the literature, both also presented higher values, which indicates a certain degree of proportionality.

The study limitations include the measurement of the total length of the tooth on its palatal surface and the palatal root length in the maxillary premolars since the literature presents only one measure for these variables, exclusively for buccal ${ }^{17-20}$. Thus, the data obtained in this study, both on the palatal surface and the buccal surface of the maxillary first premolar, in both groups tested, were compared only to the buccal measurement of the control group. Equally, the literature only presents values, for total tooth and root length, referring to the mesiobuccal roots, in the maxillary molars, and to the mesial ones, in the mandibular molars ${ }^{17-20}$. Thus, the data obtained in the distal roots of the mandibular molars, and the palatal and distobuccal roots of the maxillary molars were compared only to the measurement presented in the literature.

Al-Sudani, Basudan ${ }^{8}$ and Luz et al. ${ }^{10}$ point out that artificial teeth are seen as unsatisfactory, both by students and specialists, concerning anatomy and physical characteristics. However, studies indicate that students trained in artificial teeth are not harmed during preclinical training in Endodontics, when compared to students trained in extracted natural teeth, obtaining the same results ${ }^{4,6,9,14}$. With the increasing adherence to the market of artificial teeth, the search for models that provide more realistic experiences and even that cause greater satisfaction to dentistry students, is necessary. This study, as well as that by Mendes et al. ${ }^{15}$, presents subsidies that can help companies to improve the morphology of their artificial models.

\section{CONCLUSION}

Only the group of maxillary molars from the FS company had all values similar to those of the control group, being the most appropriate among those evaluated, for preclinical training in endodontics, from a morphometric point of view. Although the other groups present statistically significant differences when compared to the literature, the maxillary first premolars of both companies respected a certain degree of proportionality in the morphometric variations. On the other hand, the mandibular first molar in the IM group did not maintain the morphometric proportionality of the crown, as it presented a statistically significant difference in only one of the two variables.

\section{REFERENCES}

1. Gancedo-Caravia L, Bascones J, García-Barbero E, Arias A. Suitability of diferente tooth replicas for endodontic training: perceptions and detection of common erros in the performance of postgraduate students. Int Endod J. 2020;53(4):562-72. http://dx.doi.org/10.1111/iej.13251. PMid:31721237.

2. Reymus M, Fotiadou C, Kessler A, Heck K, Hickel R, Diegritz C. 3D printed replicas for endodontic education. Int Endod J. 2019 Jan;52(1):123-30. http://dx.doi.org/10.1111/iej.12964. PMid:29900562.

3. Narayanaraopeta U, AlShwaimi E. Preclinical endodontic teaching. A survey of Saudi dental schools. Saudi Med J. 2015;36(1):94-100. http://dx.doi.org/10.15537/smj.2015.1.9336. PMid:25630011.

4. Tchorz JP, Brandl M, Ganter PA, Karygianni L, Polydorou O, Vach K, et al. Pre-clinical endodontic training with artificial instead of extracted human teeth: does the type of exercise have na influence on clinical endodontic outcomes? Int Endod J. 2015 Sep;48(9):888-93.

http://dx.doi.org/10.1111/iej.12385. PMid:25266846. 
5. Robberecht L, Chai F, Dehurtevent M, Marchandise P, Bécavin T, Hornez JC, et al. A novel anatomical ceramic root canal simulator for endodontic training. Eur J Dent Educ. 2017 Nov;21(4):e1-6. http://dx.doi.org/10.1111/eje.12207. PMid:27146633.

6. Decurcio DA, Lim E, Chaves GS, Nagendrababu V, Estrela C, Rossi-Fedele G. Pre-clinical endodontic education outcomes between artificial versus extracted natural teeth: a systematic review. Int Endod J. 2019 Mar;52(8):1153-61. http://dx.doi.org/10.1111/iej.13116. PMid:30883828.

7. Holden A, Dracopoulos SA. Owning the tooth: exploring the ethical and legal issues relating to use of extracted human teeth in dental education in Australia. Aust Dent J. 2017 Jun;62(2):146-51. http://dx.doi.org/10.1111/adj.12493. PMid:27878823.

8. Al-Sudani DI, Basudan SO. Students' perceptions of pre-clinical endodontic training with artificial teeth compared to extracted human teeth. Eur J Dent Educ. 2017 Aug;21(4):e72-5. http://dx.doi.org/10.1111/eje.12223. PMid:27495270.

9. Bitter K, Gruner D, Wolf O, Schwendicke F. Artificial versus natural teeth for preclinical endodontic training: a randomized controlled trial. J Endod. 2016 Aug;42(8):1212-7. http://dx.doi.org/10.1016/j.joen.2016.05.020. PMid:27469437.

10. Luz DS, Ourique FS, Scarparo RK, Vier-Pelisser FV, Morgental RD, Waltrick SBG, et al. Preparation time and perceptions of brazilian specialists and dental students regarding simulated root canals for endodontic teaching: a preliminary study. J Dent Educ. 2015 Jan;79(1):56-63. http://dx.doi.org/10.1002/j.0022-0337.2015.79.1.tb05857.x. PMid:25576553.

11. Nassri MR, Carlik J, da Silva CR, Okagawa RE, Lin S. Critical analysis of artificial teeth for endodontic teaching. J Appl Oral Sci. 2008;16(1):43-9. http://dx.doi.org/10.1590/S1678-77572008000100009. PMid:19089288.

12. Brasil. Lei no 9.434, de 4 de fevereiro de 1997. Dispõe sobre a remoção de órgãos, tecidos e partes do corpo humano para fins de transplante e tratamento e dá outras providências. Diário Oficial da União, Brasília, 4 fevereiro, 1997.

13. Brasil. Ministério da Saúde. Diretrizes da Política Nacional de Saúde Bucal. Brasília: Ministério da Saúde; 2004.

14. Aljarbou FA, Riyahi AM. Natural versus artificial teeth in preclinical endodontic training. Int J Med Dent. 2019;23(3):419-24. http://dx.doi.org/10.1016/j.joen.2016.05.020.

15. Mendes JS, Montagner F, Melo TAF, Luisi SB. Avaliação de dentes monorradiculares artificiais utilizados para treinamento endodôntico. Rev Odontol UNESP. 2020;49:e20200018. http://dx.doi.org/10.1590/1807-2577.01820.

16. Medeiros JMF, Ferreira GS, Habitante SM, Dollinger CFAV, Forghieri AA, Haddad MS Fo. Análise da dureza vickers da superfície de dentes artificiais em resina poliéster. Rev Odontol Univ Cid São Paulo. 2014;26(1):23-37. http://dx.doi.org/10.26843/ro_unicid.v26i1.283.

17. Figún ME, Garino RR. Anatomia odontológica funcional e aplicada. Porto Alegre: Artmed; 2003.

18. Picosse M. Anatomia dentária. São Paulo: Guanabara Koogan; 1987.

19. Woelfel JB, Scheid RC. Anatomia dental. Rio de Janeiro: Guanabara-Koogan; 1984.

20. Sicher H, Tandler J. Anatomia para dentistas. São Paulo: Atheneu; 1981.

21. Reymus M, Stawarczyk B, Winkler A, Ludwig J, Kess S, Krastl G, et al. A critical evaluation of the material properties and clinical suitability of in-house printed and commercial tooth replicas for endodontic training. Int Endod J. 2020 Oct;53(10):1446-54. http://dx.doi.org/10.1111/iej.13361. PMid:32623735.

22. Bainy PT, Luisi SB, Montagner F, Melo TAF. Efeito de diferentes soluções irrigadoras na microdureza superficial Knоop de dentes artificiais. Rev Odontol UNESP. 2019;48:e20190052. http://dx.doi.org/10.1590/1807-2577.05219. 
23. Weschenfelder VM, Bainy PT, Vizzotto MB, Luisi SB, Montagner F, Melo TAF. Radiopacidade de dentes artificiais para treinamento pré-clínico de endodontia. Rev Odontol UNESP. 2019;48:e20190053. http://dx.doi.org/10.1590/1807-2577.05319.

24. Vertucci F, Seelig A, Gillis R. Root canal morphology of the human maxillary second premolar. Oral Surg Oral Med Oral Pathol. 1974 Sep;38(3):456-64. http://dx.doi.org/10.1016/0030-4220(74)90374-0. PMid:4528716.

25. Kaplan T, Sezgin GP, Sönmez-Kaplan S. Dental students' perception of difficulties concerning root canal therapy: a survey study. Saudi End J. 2020 Mar;10(1):33-8. http://dx.doi.org/10.4103/sej.sej_35_19.

26. Della Serra F, Ferreira FV. Anatomia dental. São Paulo: Arts Médicas; 1981.

27. Fernandes TMF, Sathler R, Natalício GL, Henriques JFC, Pinzan A. Comparison of mesiodistal tooth widths in Caucasian, African and Japanese individuals with Brazilian ancestry and normal occlusion. Dental Press J Orthod. 2013 Jun;18(3):130-5. http://dx.doi.org/10.1590/S2176-94512013000300021. PMid:24094023.

\section{CONFLICTS OF INTERESTS}

The authors declare no conflicts of interest.

\section{*CORRESPONDING AUTHOR}

Simone Bonato Luisi, UFRGS - Universidade Federal do Rio Grande do Sul, Faculdade de Odontologia. Departamento de Odontologia Conservadora, Rua Ramiro Barcelos, 2492, Bairro Santana, 90035-003 Porto Alegre, RS, Brasil, e-mail: simone.luisi@ufrgs.br

Received: June 29, 2021

Accepted: September 16, 2021 